\title{
Ryosuke Kuroda: Associate Editor
}

\author{
Jon Karlsson $^{1} \cdot$ Roland Becker $^{2} \cdot$ Michael T. Hirschmann $^{3} \cdot$ Volker Musahl $^{4}$
}

Published online: 5 May 2016

(C) European Society of Sports Traumatology, Knee Surgery, Arthroscopy (ESSKA) 2016

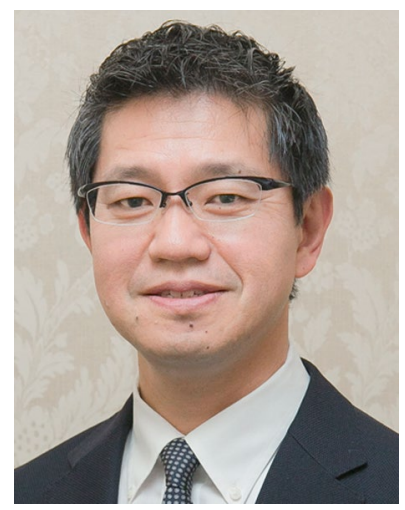

Ryosuke Kuroda, MD, PhD, has been appointed as an Associate Editor of the Knee Surgery Sports Traumatology and Arthroscopy Journal commencing May 2016.

Jon Karlsson

jon.kssta@gmail.com; jon.karlsson@telia.com

Roland Becker

roland.becker@kssta.org

Michael T. Hirschmann

Michael.Hirschmann@unibas.ch

Volker Musahl

musahlv@upmc.edu

1 Department of Orthopaedics, Sahlgrenska University Hospital, Molndal, Sweden

2 Department of Orthopaedic and Traumatology, City Hospital Brandenburg, Hochstrasse 29, 14770 Havel, Brandenburg, Germany

3 Department of Orthopaedic Surgery and Traumatology, Kantonsspital Baselland, Bruderholz, Switzerland

4 Orthopaedic Surgery and Bioengineering, UPMC Center for Sports Medicine, University of Pittsburgh, 3200 South Water Street, Pittsburgh, PA 15203, USA
Ryosuke has served as a reviewer for the journal for several years. He trained at the Graduate School of Medicine, Kobe University in Japan, graduating in 1990. His orthopaedic residency was spent at Kobe University Hospital under the leadership of Prof. Mizuno and Prof. Kurosaka, and he became a board-certified specialist in Orthopaedic Surgery in 1997.

From1997 to 1999, he spent two and a half years in Cleveland (USA) as a research fellow with Prof. Bergfeld and Prof. Andrish at the Department of Biomedical Engineering and Orthopaedic Surgery at the Cleveland Clinic. From 2002 to 2003, he was a postdoctoral research fellow with Prof. Fu and Prof. Huard at the UPMC in Pittsburgh (USA). He was then appointed as an assistant professor at the Department of Orthopaedic Surgery, Graduate School of Medicine, Kobe University. He was selected for the ISAKOS (the International Society of Arthroscopy, Knee Surgery and Orthopaedic Sports Medicine) Patellofemoral travelling fellowship in 2007 and also for the APOSSM (Asia-Pacific Orthopaedic Society of Sports Medicine)-ESSKA travelling fellowship in 2010.

His research work focuses on biology and biomechanics of the knee joint, including pivot-shift analysis, ACLderived cell, ACL remnant analysis and surgical techniques of ACL reconstruction, medial patellofemoral ligament (MPFL) reconstruction, meniscal repair and cell-based therapy for cartilage damage.

Since 2010, he has been the associate professor at the Department of Orthopaedic Surgery, Graduate School of Medicine, Kobe University. Meanwhile, he has been a visiting lecturer at the Hyogo Medical College, Hiroshima University and Kobe Pharmaceutical University since 2015.

Since 2000, Ryosuke has been an ISAKOS member and been active in the following roles: past member of ISAKOS knee committee (2009-2011), Board of Director member (since 2013) and member of the strategic committee (since 
2015). He is a member of JOSKAS (Japanese Orthopaedic Society of Knee, Arthroscopy and Sports Medicine) and became a Board of Councillors member in 2009, and he is the board member of the Japanese Society of Clinical Sports Medicine (since 2009). Furthermore, he is the education committee member of APKASS (Asia-Pacific Knee,
Arthroscopy and Sports Medicine Society) (since 2014), the member-at-large of ACL Study Group (since 2016) and the member of International Patellofemoral Study Group (since 2015). We welcome Ryosuke to the team of KSSTA editors. 